\title{
A Placebo-Controlled, Randomized, Double-Blinded, Cross-Over Phase-I Clinical Study Indicating the Safety of Topical Ankaferd Hemostat in Healthy Volunteers
}

\author{
Ozlem S. BALCIK ${ }^{1}$, Mustafa KOROGLU ${ }^{1}$, Handan CIPIL ${ }^{1}$, Osman KAFTAN ${ }^{1}$, Senem MARAL ${ }^{1}$, \\ Ayse GUREL ${ }^{1}$, Hakan GOKER ${ }^{2}$, Ibrahim C. HAZNEDAROGLU ${ }^{2}$, Ali KOSAR ${ }^{1}$ \\ ${ }^{1}$ Fatih University Faculty of Medicine, Department of Hematology, Ankara, TURKEY \\ ${ }^{2}$ Hacettepe University Faculty of Medicine, Department of Hematology, Ankara, TURKEY
}

\begin{abstract}
Ankaferd is a folkloric medicinal plant extract which has historically been used as an hemostatic agent in traditional Turkish medicine. Ankaferd Hemostat (ABS, Ankaferd BloodStopper®) includes the plants of Thymus vulgaris, Glycyrrhiza glabra, Vitis vinifera, Alpinia officinarum and Urtica dioica. The hemostatic effects of ABS have been established in the in vitro and in vivo studies in the Literature. The basic mechanism of action for ABS is the formation of an encapsulated protein network representing the focal points for the vital erythroid aggregation. The topical usage of ABS as a hemostatic agent in clinical hemorrhages and during dental interventions provided the first clues about the safety and efficacy of ABS in humans. The aim of this study is to search topical safety of ABS in a phase I randomized, double-blinded, cross-over, placebo controlled clinical study in healthy volunteers. Twenty-four healthy volunteers (11 males and 13 females, aged 18-44 years) compatible with the study protocol were enrolled into the study. In this study, topical ABS application for 120 minutes is not different from the placebo, in terms of both the local skin findings and systemic laboratory tests. Based on those data, it is concluded that topical application of ABS is safe and tolerable in humans.
\end{abstract}

Keywords: Ankaferd, Bleeding, Hemostasis, Hemorrhagic diathesis, Phase I trial

\section{ÖZET}

Topikal Ankaferd Hemostat'ın Güvenilirliğini Yansıtan Sağlıklı Gönüllülerde Yapılmış Plasebo Kontrollü, Randomize, Çift Kör, Çapraz Geçişli Faz-I Klinik Çalışma

Ankaferd, geleneksel Türk tıbbında hemostatik ajan olarak kullanılan bir bitkisel bileşiktir. Ankaferd Hemostat (ABS, Ankaferd BloodStopper $\left.{ }^{\circledR}\right)$ Thymus vulgaris, Glycyrrhiza glabra, Vitis vinifera, Alpinia officinarum ve Urtica dioica bitkileri ABS içeriğinde yer almaktadır. ABS hemostatik etkileri, literatürde in vitro ve in vivo çallşmalarda gösterilmiştir. ABS'nin temel etki mekanizması, canlı eritroid aggregasyon için fokal odaklar teşkil eden bir protein ağının oluşturulmasına dayanmaktadır. Topikal ABS'nin insanlarda bir hemostatik ajan olarak etkinlik ve güvenilirliliğine ilişkin ilk bulgular, klinik kanamalar ve dental girişimlerdeki ABS kullanım verilerine dayanmaktadır. Bu çalışmanın amacı; randomize, çift-kör, çapraz geçişli, plasebo-kontrollü, bir çalışma ile sağlıklı gönüllülerde topikal ABS'nin güvenilirliliğini araştırmaktır. Yirmi dört sağlıkı gönüllü (11 erkek ve 13 kadın, 18-44 yaşlarında) çalışma protokolü ile uyumlu olarak çalışmaya alınmışlardır. Çalışma sonuçlarına göre 120 dakikalık topikal ABS uygulaması lokal cilt etkileri ve sistemik laboratuvar testleri yönünden plasebo uygulamasından farksız sonuçlar vermiştir. Bu verilere dayanarak insanlarda topikal ABS uygulamasının güvenilir olduğu sonucuna varımıştır.

Anahtar Kelimeler: Ankaferd, Kanama, Hemostaz, Hemorajik diyatez, Faz I çalışma 


\section{INTRODUCTION}

Ankaferd Hemostat (Ankaferd Blood Stopper, ABS) includes a standardized preparation of the plants Thymus vulgaris, Glycyrrhiza glabra, Vitis vinifera, Alpinia officinarum and Urtica dioica. ${ }^{1}$ Each one of these plants is effective for the actions on the endothelium, blood cells, angiogenesis, cell proliferation, vascular dynamics, and critical mediators. ${ }^{2}$ The plant extract has historically been used as a hemostatic agent in traditional Turkish medicine for centuries.-5 The basic mechanism of action for the ABS is the formation of an encapsulated protein network that provides focal points for vital erythroid aggregation. ${ }^{2}$ ABS-induced protein network formation with blood cells particularly erythrocytes covers the primary and secondary haemostatic system without disturbing the individual coagulation factors. This unique mechanism provides an advantage for ABS in comparison to the other hemostatic agents. The exposure to ABS to a given area provides physiological hemostatic process together with the tissue oxygenation. ${ }^{2,6,7}$ ABS causes an encapsulated protein web formation which will induce erythrocyte aggregation, affecting the fibrinogen gamma-erythrocyte interactions. ${ }^{2}$ ABS critically affects protein structures for instance; the aggregation in the protein fibrils has been demonstrated by the addition of ABS to the pancreatic liquids. ${ }^{8}$

There are distinct important molecular components of the Ankaferd-induced hemostatic network. Vital erythroid aggregation takes place with the spectrin, ankyrin and actin proteins on the membrane of red blood cells. Essential erythroid proteins (Ankyrin, recurrent and FYVE bundle containing protein 1, Spectrin alpha, Actin-depolimerisation factor, Actin-depolimerizing factor, LIM bundle and actine binding subunit 1 isoform a, LIM bundle and actine binding subunit 1 isoform $b$, NADP-dependent malic enzyme, NADH dehydrogenase (Ubiquinone) 1 alpha subcomplex, Mitochondrial NADP (+) dependent malic enzyme 3, Ribulose bisphosphatecarbocsilase large chain, Maturase $\mathrm{K}$ ) and the required ATP bioenergy (ATP synthase, ATP synthase beta subunit, ATP synthase alpha subunit, ATP-binding protein $\mathrm{C} 12$, TP synthase $\mathrm{H}+$ transporter protein, ADF, Alpha-1,2-glycosyltransferase ALG10A) are included in the protein library of Ankaferd. Ankaferd also up-regulates the GATA/FOG transcription system affecting the erythroid functions and urotensin II. ${ }^{19} \mathrm{ABS}$ has been shown to act as a topical biological modifier on vascular endothelial at the cellular level via the Protease-Activated Receptor I (PAR-1).$^{10}$ Cytotoxic effects of ABS have been shown on the human pulp fibroblasts depending on the dose concentrations. ${ }^{11}$

ABS is a hemostatic agent that can be used effectively in the clinical practices, such as to control external bleedings, dental/ periodontal hemorrhages, skin bleedings and/or superficial mucosal blood leakages. ${ }^{12-15}$ The hemostatic effects of ABS have been demonstrated by in vitro and in vivo studies in the Literature ${ }^{16-29}$ The topical application of ABS as a hemostatic agent in the external hemorrhages and during dental interventions constituted the first hints about the safety and efficacy of ABS in humans..$^{13} \mathrm{~A}$ recent in vitro study suggested that topical application of ABS to ocular surfaces could affect cellular constituents. ${ }^{30}$

The aim of this study is to demonstrate topical safety of ABS in a phase I placebo controlled, randomized, and double-blinded, cross-over clinical study in healthy human volunteers in order to establish further controlled clinical trials focused on the efficacy of ABS in different clinical settings.

\section{PATIENTS AND METHODS}

A placebo-controlled, randomized, double-blinded, cross-over phase I clinical study to demonstrate the safety of ABS usage in healthy volunteers is planned to demonstrate the safety of topical ABS usage in humans; the required ethical approval is obtained from the local and central ethical committee. The objective of this study is to show that the safety of topical usage of ABS in healthy volunteers is equivalent/comparable to placebo.

Healthy, volunteering for enrollment with written informed consents, without any skin disease, not pregnant or lactating (for females), without existing or history of serious systemic or mental disease, without hypersensitivity history against herbal substances in ABS, without alcohol addiction or regular alcohol usage, non-smoker 24 persons between 18-44 years old are enrolled in the study.

This is a double-blinded, randomized, placebo controlled, cross-over study, with a 5 days' washout period between the cross-over periods. In the 


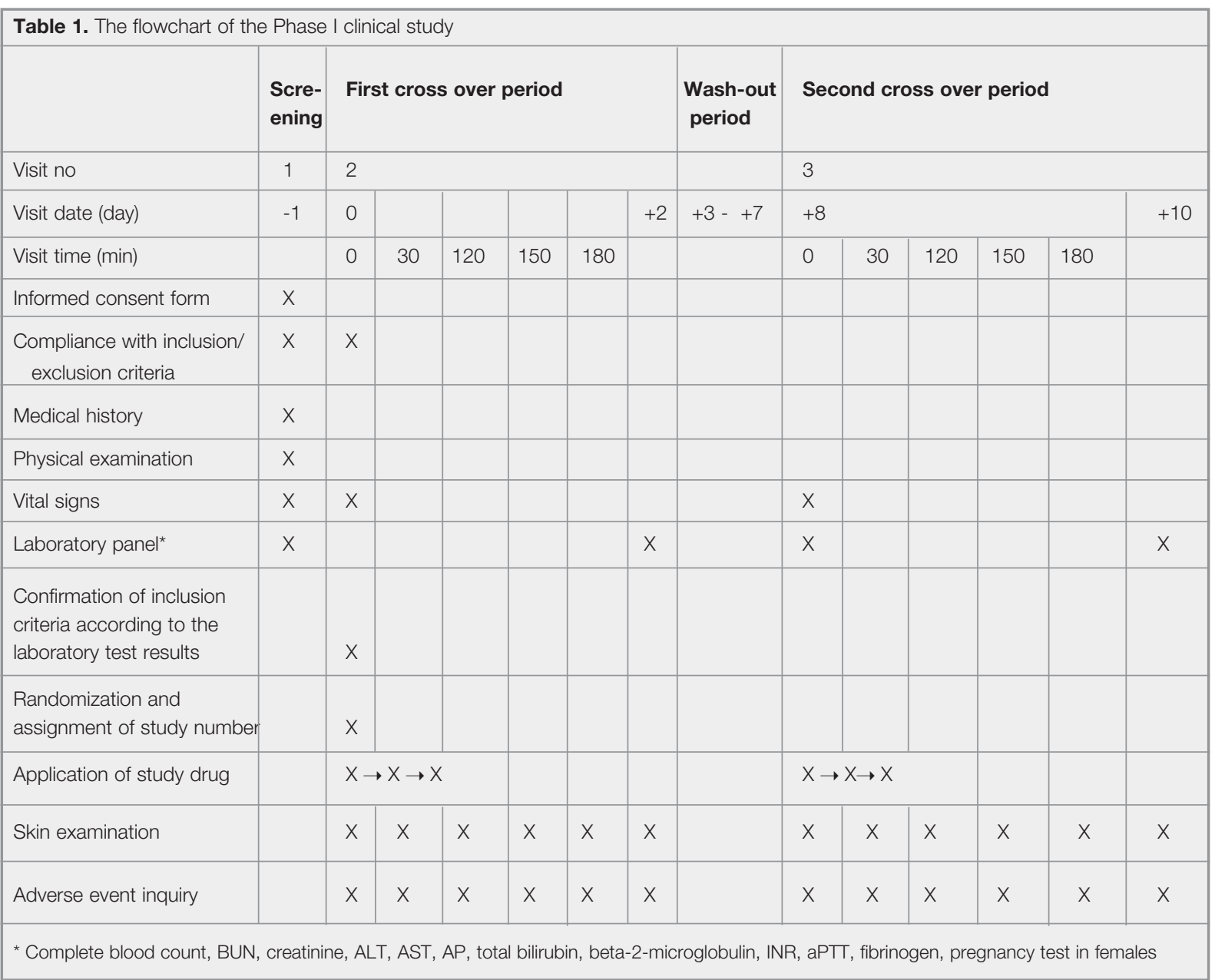

screening visit at the baseline, the volunteers are evaluated for inclusion and exclusion criteria suitability and basal laboratory tests are evaluated. In the visit performed one day after the screening visit, the eligibility of the volunteer for the study is confirmed again and, the volunteer was randomized to $\mathrm{ABS}$ or placebo group and 1st cross over period is initialized. The study procedures and application times are as follows:

0. minute: Primarily, questioning the volunteer regarding symptoms about skin and skin examination is performed. Afterwards, $2.5 \times 7 \mathrm{~cm}$ ABS or placebo soaked pad is placed at the non-dominant arm, at the inside of the forearm (washed with soap and dried) on a hairless area and the volunteer is kept waiting in the outpatient clinic for 30 minutes.

30th minute: Before removing the pad, the volunteer is questioned regarding adverse events related with skin; afterwards, the gauze is untied and pad is removed and the skin is examined and a novel 2.5 $\mathrm{x} 7 \mathrm{~cm}$ ABS or placebo soaked pad is placed at the same area. The volunteer is kept waiting in the outpatient clinic for 90 minutes more.

120th minute: Before removing the pad, the volunteer is questioned regarding adverse events related with skin; afterwards, the gauze is untied and pad is removed and the skin is examined. The volunteer is kept waiting in the outpatient clinic for 30 minutes.

150th minute: Questioning regarding adverse event related with skin is performed and the skin is examined. The volunteer is kept waiting in the outpatient clinic for 30 minutes.

180th minute: Adverse event questioning regarding the skin is performed and the skin is examined. The volunteer is sent, to return after 48 hours.

48th hour: After performing adverse event questioning regarding the skin with the volunteer, skin examination is performed and the laboratory tests are repeated afterwards. 
After the first cross over period, a wash-out period for 5 days has passed and, after the wash-out period, the treatment of the patients are changed in the second cross over period visit and all study procedures are performed in the same order and method as the first cross over period.

The laboratory tests are repeated for 4 times: in the screening visit, at the end of first cross over period, at the beginning and, at end of the second cross over period. Laboratory panel consisted of the following tests: Complete blood count, BUN, creatinine, ALT, AST, AP, total bilirubin, beta-2-microglobulin, INR, aPTT and fibrinogen.

The flowchart of the study is schematized in Table 1 .

\section{STATISTICAL METHODOLOGY}

Randomization: Volunteers who are appropriate for study, was randomized by a computer programme as first Ankaferd ${ }^{\circledR}$ BloodStopper ${ }^{\circledR}$ than placebo or total opposite. Randomization programme was created by randomized permutations which used pseudo-randomized numbers.

Break of Blanking: In the periods of medical treatment in double blind groups, medical emergency was not happened and was not decided to break the blanking. Therefore all the study was continued by randomization.

The envelope of double blind medication was given to the centre of study. The envelope which has the randomized individuals number was opened and learned the medication was given. First letter of the name of individual who has broken blanking was noted with the reason of breaking and date. Adverse reactions and details were recorded to adverse reaction page.

Analysis of Data: In the study essentially to show equivalency or indifference between Ankaferd ${ }^{\circledR}$ BloodStopper ${ }^{\circledR}$ and placebo was targeted.

Analysis was performed in per-protocol (PP). Severe results were analysed between the results of 30 min- 2 hour- 24 hour- 48 hour assessment. Average and median etc. results of analysis was estimated and compared. Moreover categorized varied as ratio of results which are over the limits was compared.

In the study which was considered as a cross-section, ANOVA or ANCOVA methods was performed.
Compare of categorized varied, no effect of arrengement and washout period was shown and Ankaferd ${ }^{\circledR}$ BloodStopper ${ }^{\circledR}$ periods and placebo periods was associated and analysed by McNemar test.

\section{RESULTS}

A total of 24 volunteers were included in the study, with age mean \pm SD $30.9 \pm 4.7$ years, aged between 22-44 years. Of the volunteers included, 11 were male and, 13 were female. The mean BMI value of the volunteers was $24.3 \pm 3.0 \mathrm{~kg} / \mathrm{m}^{2}$.

The mean pulse rate in the volunteers included in the study was $82.9 \pm 22.1$ beats/min. Mean pulse rate stayed between 79 and 81 beats/min during both study periods. Systolic and diastolic blood pressures were $118 \pm 10 \mathrm{mmHg}$ and $74 \pm 7 \mathrm{mmHg}$. Mean SBP stayed between 115 and $118 \mathrm{mmHg}$ during both study periods, and mean DBP stayed between $73-76 \mathrm{mmHg}$.

All biochemical, hematological and hemostasis changes in the parameters between before and after pad, and percent change amounts were not different between ABS and placebo (Table 2-4).

During the ABS period, skin findings were reported in 5 volunteers (20.8\%). In three volunteers burning sensation, in one volunteer itching, in one volunteer both itching and burning sensation appeared. These complaints appeared 5-40 minutes after pad application and continued for 5 to 80 minutes. Severity of the complaint was reported as "mild" by all of the 5 volunteers (Table 5).

During the placebo period, skin findings were reported in 4 volunteers $(16.7 \%)$. In one volunteer itching, in three volunteers both itching and burning sensation were appeared. These complaints appeared after 5-35 minutes after pad application and continued for 10 to 70 minutes. The severity of the complaint was reported as "Mild" by 3 and "Moderate" by one of this 4 volunteer with complaint (Table 5).

In this randomized, placebo-controlled, cross-over phase I clinical study in healthy volunteers, it is observed that topical ABS pad application for $120 \mathrm{mi}-$ nutes is not different from the placebo in terms of the both local skin findings and systemic laboratory tests. Based on those data, it is concluded that topical application of ABS is safe. 


\begin{tabular}{|c|c|c|c|}
\hline & $\begin{array}{l}\text { ABS } \\
\text { Mean } \pm \text { SD }\end{array}$ & $\begin{array}{l}\text { Placebo } \\
\text { Mean } \pm \text { SD }\end{array}$ & $\begin{array}{l}\mathrm{p} \\
\text { value }\end{array}$ \\
\hline \multicolumn{4}{|l|}{ BUN, mg/dL } \\
\hline Before & $12.75 \pm 3.37$ & $12.71 \pm 3.18$ & \\
\hline After & $13.08 \pm 3.72$ & $13.92 \pm 3.81$ & \\
\hline Difference & $0.33 \pm 1.81$ & $1.21 \pm 3.04$ & 0.20 \\
\hline Difference, \% & $3.03 \pm 12.73$ & $12.03 \pm 24.33$ & 0.11 \\
\hline \multicolumn{4}{|c|}{ Creatinine, mg/dL } \\
\hline Before & $0.77 \pm 0.18$ & $0.75 \pm 0.18$ & \\
\hline After & $0.73 \pm 0.21$ & $0.75 \pm 0.20$ & \\
\hline Difference & $-0.04 \pm 0.07$ & $-0.01 \pm 0.09$ & 0.23 \\
\hline Difference, \% & $-5.60 \pm 10.73$ & $-1.21 \pm 13.44$ & 0.21 \\
\hline \multicolumn{4}{|l|}{ ALT, IU/L } \\
\hline Before & $20.46 \pm 12.01$ & $19.50 \pm 7.91$ & \\
\hline After & $20.25 \pm 9.60$ & $21.08 \pm 11.67$ & \\
\hline Difference & $-0.21 \pm 4.85$ & $1.58 \pm 4.53$ & 0.29 \\
\hline Difference, \% & $3.69 \pm 29.85$ & $5.46 \pm 13.97$ & 0.80 \\
\hline \multicolumn{4}{|l|}{ AST, IU/L } \\
\hline Before & $18.38 \pm 6.35$ & $17.50 \pm 4.66$ & \\
\hline After & $16.92 \pm 4.28$ & $17.75 \pm 5.49$ & \\
\hline Difference & $-1.46 \pm 3.95$ & $0.25 \pm 2.97$ & 0.13 \\
\hline Difference, \% & $-4.73 \pm 17.33$ & $2.10 \pm 18.42$ & 0.21 \\
\hline \multicolumn{4}{|c|}{ Alkaline phosphatase, IU/L } \\
\hline Before & $71.75 \pm 20.37$ & $71.79 \pm 22.16$ & \\
\hline After & $67.29 \pm 20.22$ & $69.75 \pm 19.77$ & \\
\hline Difference & $-4.46 \pm 12.91$ & $-2.04 \pm 5.55$ & 0.36 \\
\hline Difference, \% & $-5.15 \pm 14.31$ & $-2.07 \pm 7.32$ & 0.33 \\
\hline \multicolumn{4}{|c|}{ Total bilirubin, mg/dL } \\
\hline Before & $0.63 \pm 0.19$ & $0.63 \pm 0.19$ & \\
\hline After & $0.62 \pm 0.20$ & $0.62 \pm 0.19$ & \\
\hline Difference & $0.00 \pm 0.14$ & $-0.01 \pm 0.14$ & 0.82 \\
\hline Difference, \% & $1.92 \pm 23.66$ & $0.77 \pm 22.09$ & 0.87 \\
\hline \multicolumn{4}{|c|}{ Beta-2-MG, mg/dL } \\
\hline Before & $0.80 \pm 0.52$ & $0.63 \pm 0.54$ & \\
\hline After & $0.68 \pm 0.64$ & $0.75 \pm 0.47$ & \\
\hline Difference & $-0.12 \pm 0.43$ & $0.13 \pm 0.39$ & 0.07 \\
\hline Difference, \% & $-26.18 \pm 52.36$ & $5.05 \pm 44.56$ & 0.64 \\
\hline
\end{tabular}

\section{DISCUSSION}

This phase I double-blinded, randomized, crossover, placebo controlled clinical study with a 5 days' wash-out period between the cross-over periods in healthy volunteers indicated the safety of

\begin{tabular}{|c|c|c|c|}
\hline & $\begin{array}{l}\text { ABS } \\
\text { Mean } \pm \text { SD }\end{array}$ & $\begin{array}{l}\text { Placebo } \\
\text { Mean } \pm \text { SD }\end{array}$ & $\begin{array}{c}p \\
\text { value }\end{array}$ \\
\hline \multicolumn{4}{|c|}{ Haemoglobin, g/dL } \\
\hline Before & $13.48 \pm 1.66$ & $13.50 \pm 1.87$ & \\
\hline After & $13.33 \pm 1.67$ & $13.38 \pm 1.87$ & \\
\hline Difference & $-0.15 \pm 0.47$ & $-0.13 \pm 0.37$ & 0.83 \\
\hline Difference, \% & $-1.13 \pm 3.50$ & $-0.89 \pm 2.81$ & 0.81 \\
\hline \multicolumn{4}{|l|}{ Haematocrit, \% } \\
\hline Before & $40.08 \pm 4.40$ & $40.10 \pm 5.25$ & \\
\hline After & $39.90 \pm 4.66$ & $39.76 \pm 5.05$ & \\
\hline Difference & $-0.17 \pm 1.50$ & $-0.33 \pm 1.28$ & 0.73 \\
\hline Difference, \% & $-0.44 \pm 3.73$ & $-0.71 \pm 3.25$ & 0.82 \\
\hline \multicolumn{4}{|c|}{ Leucocyte, $1000 / \mathrm{mm}^{3}$} \\
\hline Before & $6.90 \pm 1.57$ & $6.96 \pm 1.87$ & \\
\hline After & $6.45 \pm 1.24$ & $6.75 \pm 1.88$ & \\
\hline Difference & $-0.45 \pm 1.11$ & $-0.21 \pm 1.05$ & 0.40 \\
\hline Difference, \% & $-5.09 \pm 12.74$ & $-1.84 \pm 15.25$ & 0.37 \\
\hline \multicolumn{4}{|c|}{ Erythrocyte, million $/ \mathrm{mm}^{3}$} \\
\hline Before & $5.07 \pm 0.48$ & $5.06 \pm 0.52$ & \\
\hline After & $5.02 \pm 0.47$ & $5.01 \pm 0.53$ & \\
\hline Difference & $-0.05 \pm 0.18$ & $-0.05 \pm 0.14$ & 0.95 \\
\hline Difference, \% & $-0.87 \pm 3.47$ & $-0.96 \pm 2.87$ & 0.93 \\
\hline \multicolumn{4}{|c|}{ Thrombocyte, $1000 / \mathrm{mm}^{3}$} \\
\hline Before & $293.25 \pm 45.72$ & $290.33 \pm 47.42$ & \\
\hline After & $296.33 \pm 49.11$ & $296.17 \pm 53.22$ & \\
\hline Difference & $3.08 \pm 19.65$ & $5.83 \pm 22.82$ & 0.56 \\
\hline Difference, \% & $1.04 \pm 6.20$ & $2.05 \pm 7.93$ & 0.46 \\
\hline
\end{tabular}

ABS. Topical hemostatic efficacy of ABS has been previously tested in animals with normal $1^{18,22}$ and defective hemostasis. ${ }^{19,31}$ Numerous studies demonstrated the haemostatic effects of topical ABS application in the animals with normal ${ }^{14,16,18,20,21}$ and defective hemostasis ${ }^{19,22}$ have set the preclinical stage for the development of this hemostatic product. Short-term hematological and biochemical safety of the oral systemic administration of Ankaferd to rabbits have been shown. ${ }^{17}$ Acute mucosal toxicity, hematotoxicity, hepatotoxicity, nephrotoxicity, and biochemical toxicity were not observed during the short-term follow-up of the animals. ${ }^{17}$ Those preclinical results reflect a starting point to search any possible systemic confounding effect of ABS when applied to internal topical surfaces. 


\begin{tabular}{|c|c|c|c|}
\hline & $\begin{array}{l}\text { ABS } \\
\text { Mean } \pm \text { SD }\end{array}$ & $\begin{array}{l}\text { Placebo } \\
\text { Mean } \pm \text { SD }\end{array}$ & $\begin{array}{l}p \\
\text { value }\end{array}$ \\
\hline \multicolumn{4}{|c|}{ Prothrombin time, secs } \\
\hline Before & $11.37 \pm 1.12$ & $11.10 \pm 0.70$ & \\
\hline After & $11.23 \pm 0.65$ & $11.25 \pm 0.61$ & \\
\hline Difference & $-0.14 \pm 1.27$ & $0.15 \pm 0.55$ & 0.31 \\
\hline Difference, \% & $-0.57 \pm 8.64$ & $1.56 \pm 4.93$ & 0.32 \\
\hline \multicolumn{4}{|l|}{ INR, \% } \\
\hline Before & $0.92 \pm 0.04$ & $0.92 \pm 0.06$ & \\
\hline After & $0.93 \pm 0.06$ & $0.92 \pm 0.05$ & \\
\hline Difference & $0.01 \pm 0.05$ & $0.00 \pm 0.05$ & 0.85 \\
\hline Difference, \% & $0.75 \pm 5.92$ & $0.51 \pm 5.05$ & 0.89 \\
\hline \multicolumn{4}{|l|}{ aPTT, secs } \\
\hline Before & $32.54 \pm 2.70$ & $32.17 \pm 2.89$ & \\
\hline After & $30.09 \pm 3.00$ & $29.69 \pm 2.07$ & \\
\hline Difference & $-2.45 \pm 2.02$ & $-2.48 \pm 2.77$ & 0.96 \\
\hline Difference, \% & $-7.48 \pm 5.81$ & $-7.27 \pm 7.40$ & 0.91 \\
\hline \multicolumn{4}{|c|}{ Fibrinogen, mg/dL } \\
\hline Before & $285.28 \pm 48.05$ & $275.88 \pm 44.06$ & \\
\hline After & $230.17 \pm 28.46$ & $235.07 \pm 37.31$ & \\
\hline Difference & $-55.11 \pm 33.32$ & $-40.81 \pm 30.26$ & 0.11 \\
\hline Difference, \% & $-18.21 \pm 10.00$ & $-14.25 \pm 10.39$ & 0.21 \\
\hline
\end{tabular}

The usage of ABS as a hemostatic agent in external hemorrhages and in dental treatment in humans constituted the first hints on ABS's safety and efficacy in humans. ${ }^{13}$ Physiological cell-based coagulation could be clinically managed via topical ABS application to prevent and treat bleeding in many distinct clinicopathological states. ${ }^{14,22,32,33}$ The results of this Phase I study offers the required set-up for further controlled clinical trials focused on the efficacy of ABS in different clinical settings.

The in vitro antibacterial activity of ABS was evaluated by Akkoç et al. ${ }^{34,35}$ In this study, the antagonistic activity of ABS is evaluated against 26 indicator strains consisting of 26 indicator strains Gram positive and Gram negative bacteria, in human and food pathogens, using agar diffusion method, and it is demonstrated that it is effective against all strains. Nisin, a food preservative bacteriosin used as a control, is found to be inactive against Gram nega-

\begin{tabular}{|c|c|c|c|c|}
\hline & \multicolumn{2}{|c|}{ ABS } & \multicolumn{2}{|c|}{ Placebo } \\
\hline & $\mathrm{n}$ & $\%$ & $\mathrm{n}$ & $\%$ \\
\hline Any skin finding & 5 & 20.9 & 4 & 16.7 \\
\hline Itching in the skin & 1 & 4.2 & 1 & 4.2 \\
\hline Burning sensation in the skin & 3 & 12.5 & - & - \\
\hline $\begin{array}{l}\text { Burning sensation and } \\
\text { itching in the skin }\end{array}$ & 1 & 4.2 & 3 & 12.5 \\
\hline No skin finding & 19 & 79.2 & 20 & 83.3 \\
\hline Skin lesion & $p=$ & 0.71 & & \\
\hline Itching in the skin & $p=$ & 0.38 & & \\
\hline Burning sensation in the skin & $p=$ & 0.68 & & \\
\hline Starting time (min) & $\mathrm{n}$ & $\%$ & $\mathrm{n}$ & $\%$ \\
\hline 5 & 1 & 4.2 & 2 & 8.3 \\
\hline 10 & 3 & 12.5 & - & - \\
\hline 15 & - & - & 1 & 4.2 \\
\hline 35 & - & - & 1 & 4.2 \\
\hline 40 & 1 & 4.2 & - & - \\
\hline Duration (min) & $\mathrm{n}$ & $\%$ & $n$ & $\%$ \\
\hline 5 & 1 & 4.2 & - & - \\
\hline 10 & 2 & 8.3 & 1 & 4.2 \\
\hline 25 & - & - & 1 & 4.2 \\
\hline 40 & 1 & 4.2 & - & - \\
\hline 50 & - & - & 1 & 4.2 \\
\hline 70 & - & - & 1 & 4.2 \\
\hline 80 & 1 & 4.2 & - & - \\
\hline Intensity & $\mathrm{n}$ & $\%$ & $n$ & $\%$ \\
\hline Mild & 5 & 20.8 & 3 & 12.5 \\
\hline Moderate & - & - & 1 & 4.2 \\
\hline
\end{tabular}

tive strains. In addition to its high inhibitor activity against human and food pathogens, Gram positive and Gram negative bacteriae, it is observed that ABS is more stable than nisin in various temperatures and in the presence of enzymes. ${ }^{35}$ The antimicrobial activity of Ankaferd was tested against many pathogens. ${ }^{36}$ The isolates included A. baumannii, E. coli, K. pneumonia, $P$. aeruginosa, Enterobacter spp., Stenotrophomonas maltophilia, MRSA, methicillin resistant coagulase negative Staphylococcus, vancomycin susceptible Enterococcus and VRE. They have reported that Ankaferd was active against all these isolates, with zones of inhibition 
which were within the $10-18 \mathrm{~mm}$ diameter range. Antibacterial activities of Ankaferd against several gram positive and gram negative food and human pathogens, were also reported in another study. ${ }^{35}$ Consequently, in addition to its haemostatic effects in haemorrhagic wounds' healing, it is pointed out that its antimicrobial property can also be beneficial, and ABS has the potential usage for preventing against various type bacterial pathogens.

Exaggerated bleeding, particularly in patients with hereditary or acquired hemorrhagic diathesis, is a challenging problem in the clinic on a daily basis. Antithrombotic, procoagulant, and antifibrinolytic medications are frequently used for the management of bleeding. Ankaferd-induced formation of the protein network covers the entire physiological hemostatic process without unequally affecting any individual clotting factor. ${ }^{1,2,4-42} \mathrm{ABS}$ may, therefore, be effective both in individuals with normal haemostatic parameters and in patients with deficient primary haemostasis and/or secondary haemostasis. After the approval of Ankaferd for the management of dental bleeding by Turkish Ministry of Health, ABS has been added to the protocols of prevention and treatment of exaggerated hemorrhage due to dental procedures in Turkey. In a few retrospective studies, controlling clinical critical bleeding states associated with either normal or defective hemostasis have been examined. ${ }^{43}$ The patients with bleeding diathesis about controlling critical bleedings that could not be controlled with standard antihaemorrhagic methods, with topical ABS are present. ${ }^{44,45}$ Future controlled trials shall also be performed to fully elucidate the efficacy of ABS in those difficult clinical settings with hemorrhagic diathesis.

\section{REFERENCES}

1. Haznedaroglu IC. Molecular basis of the pleiotropic effects of Ankaferd Blood Stopper. IUBMB Life 61: 290, 2009.

2. Goker H, Haznedaroglu IC, Ercetin S, et al. Haemostatic actions of the folkloric medicinal plant extract ankaferd blood Stopper (R). J Int Med Res 36: 163-170, 2008.

3. Haznedaroglu IC. Time to take a healthier view of history. Nature 396: 108, 1998.

4. Haznedaroglu IC, Goker H. Haemostatic actions of the folkloric medicinal plant extract Ankaferd Blood Stopper (Response). J Int Med Res 36:1448-1449, 2008.
5. Beyazit $\mathrm{Y}, \mathrm{Kurt} \mathrm{M}$, Kekilli M, et al. Evaluation of hemostatic effects of Ankaferd as an alternative medicine. Altern Med Rev 15: 329-336, 2010.

6. Akar N, Demiralp DO, Haznedaroglu IC, et al. Functional Proteomics of Ankaferd Blood Stopper. Blood 112: 4103, 2008.

7. Aydin S. Haemostatic actions of the folkloric medicinal plant extract Ankaferd Blood Stopper (R). J Int Med Res 37: 279, 2009.

8. Karaman K, Celep B, Bostanci EB, et al. Effects of Ankaferd Blood Stopper on pancreatic fluid: An in vitro study. ANZ J Surg 80: 946-947, 2010.

9. Yilmaz E, Gulec S, Haznedaroglu IC, et al. Effects of Ankaferd on HUVEC transcription factors and erythrocyte protein profile. In: Haznedaroglu IC, Goker H, Ozdemir O, et al., editors. Ankaferd: Scientific Perspectives and Basic-Clinical Data. Istanbul, Naviga Publications, 2008: 60.

10. Karabiyik A, Gulec S, Yilmaz E, et al. Reversible Protease-Activated Receptor I Downregulation Mediated by Ankaferd Blood Stopper Inducible With Lipopolysaccharides Inside the Human Umbilical Vein Endothelial Cells. Clin Appl Thromb Hemost 17: E165-170, 2011.

11. Odabaş ME, Erturk M, Cinar $\mathrm{C}$, et al. Cytotoxicity of a new hemostatic agent on human pulp fibroblasts in vitro. Med Oral Patol Oral Cir Bucal 16: e584-7, 2011.

12. Arslan S, Haznedaroglu IC, Oz B, et al. Endobronchial application of Ankaferd blood stopper to control profuse lung bleeding leading to hypoxemia and hemodynamic instability. Resp Med 2:144-146, 2009.

13. Erçetin S, Haznedaroğlu IC, Kurt M, et al. Safety and efficacy of Ankaferd BloodStopper $\AA$ in dental surgery and bleeding. UHOD 20: 1-5, 2010.

14. Koray M, Ergun S, Saruhanoglu A, et al. Use of a new local haemostatic agent Ankaferd blood stopper after surgical excision of eruption cyst: a case report. Int $J$ Oral Maxillofacial Surg 38: 558, 2009.

15. Kurt M, Kacar S, Onal IK, et al. Ankaferd Blood Stopper as an effective adjunctive hemostatic agent for the management of life-threatening arterial bleeding of the digestive tract. Endoscopy 40 Suppl 2:E262. 2008.

16. Akgul T, Huri E, Ayyıldız A, et al. Haemostatic and Histopathological Effects of Ankaferd Blood Stopper, on Penile Cavernosal Tissue in Rat. UHOD 19: 159-165, 2009.

17. Bilgili H, Captug $\mathrm{O}$, Kosar A, et al. Oral Systemic Administration of Ankaferd Blood Stopper Has No ShortTerm Toxicity In An "In Vivo" Rabbit Experimental Model. Clin Appl Thromb Hemost 16: 533-536, 2010.

18. Bilgili H, Kosar A, Kurt M, et al. Hemostatic Efficacy of Ankaferd Blood Stopper (R) in a Swine Bleeding Model. Med Principl Practice 18:165-169, 2009.

19. Cipil H, Kosar A, Kaya A, et al. In Vivo Hemostatic Effect of the Medicinal Plant Extract Ankaferd Blood Stopper in Rats Pretreated With Warfarin. Clin Appl Thromb Hemost 15: 270-276, 2009. 
20. Huri E, Akgul T, Ayyildiz A, et al. Hemostatic Role of a Folkloric Medicinal Plant Extract in a Rat Partial Nephrectomy Model: Controlled Experimental Trial. J Urol 181: 2349-2354, 2009.

21. Germiyanoğlu C, Huri E, Akgül T, et al. Invivo Hemostatic Effect of Ankaferd Blood Stopper in Rat Major Renal Trauma Model: Controlled Trial of Novel Hemostatic Agent. UHOD 20: 206-211, 2010.

22. Karakaya K, Ucan HB, Tascilar O, et al. Evaluation of a new hemostatic agent Ankaferd Blood Stopper in experimental liver laceration. J Invest Surg 22: 201206, 2009.

23. Ozaslan E, Purnak T, Yildiz A, Haznedaroglu IC. A new candidate as a hemostatic agent for difficult situations during variceal bleeding: Ankaferd blood stopper. Saudi J Gastroenterol 17: 145-148, 2011.

24. Kılıçgün A, Sarıkaş NG, Korkmaz T, et al. Effect of Ankaferd Blood Stopper on air leakage in the lung and prevention of bleeding: an experimental study. J Cardiothorac Surg 6: 20, 2011.

25. Okten S, Kurt M, Onal IK, Haznedaroglu IC. Use of Ankaferd Blood Stopper for controlling actively bleeding fundal varices. Singapore Med J 52: e11-2, 2011.

26. Ozaslan E, Purnak T, Haznedaroglu IC. Ankaferd Blood Stopper in Gl bleeding: alternative for everything? Gastrointest Endosc 73: 185-186, 2011.

27. Zulfikar OB, Emiroglu HH, Kebudi R. Nasogastric application of topical Ankaferd Blood Stopper for bleeding from primary esophageal adenocarcinoma in a child with disseminated intravascular coagulation. Dig Liver Dis 43: 247-248, 2011.

28. Ergenoglu MU, Yerebakan H, Kucukaksu DS. A new practical alternative for the control of sternal bleeding during cardiac surgery: Ankaferd Blood Stopper. Heart Surg Forum 13: E379-80. 2010.

29. Beyazit $Y$, Köklü $S$, Akbal E, et al. Successful treatment of endoscopic sphincterotomy-induced early hemorrhage with application of Ankaferd Blood Stopper. Gastrointest Endosc 72: 1325-1326, 2010.

30. Alpay A, Evren C, Bektaş S, et al. Effects of the folk medicinal plant extract Ankaferd Blood Stopper(®) on the ocular surface. Cutan Ocul Toxicol 30: 280-285, 2011.

31. Kosar A, Cipil HS, Kaya A, et al. The efficacy of Ankaferd Blood Stopper in antithrombotic drug-induced primary and secondary hemostatic abnormalities of a rat-bleeding model. Blood Coagul Fibrinolysis 20: 185190, 2009.

32. Kurt M, Disibeyaz S, Akdogan M, et al. Endoscopic application of Ankaferd blood stopper as a novel experimental treatment modality for upper gastrointestinal bleeding: A case report. Am J Gastroenterol 103: 2156-2158, 2008.

33. Kurt M, Oztas E, Kuran S, et al. Tandem oral, rectal, and nasal administrations of Ankaferd Blood Stopper to control profuse bleeding leading to hemodynamic instability. Am J Emerg Med 27: 631 e1-631 e2, 2009.
34. Akkoc N, Akcelik M, Haznedaroglu I, et al. In vitro anti-bacterial activities of Ankaferd blood stopper. Int J Lab Hematol 30: 95, 2008.

35. Akkoc N, Akcelik M, Haznedaroglu IC, et al. In Vitro Anti-Bacterial Activities of Ankaferd Medicinal Plant Extract. Turkiye Klinikleri Tip Bilimleri Dergisi 29: 410415, 2009.

36. Fisgin NT, Cayci YT, Coban AY, et al. Antimicrobial activity of plant extract Ankaferd Blood Stopper (R). Fitoterapia 80: 48-50, 2009.

37. Aktas, A, Er N, Onur MA. Effects of Ankaferd Blood Stopper® on Vascular Response in Rat Carotid Artery. UHOD 20: 156-162, 2010.

38. Albayrak $\mathrm{CU}$, Caliskan $\cup$. Haemostatic actions of the folkloric medicinal plant extract Ankaferd Blood Stopper. J Int Med Res 36: 1447-1448, 2008.

39. Dogan OF, Ozyurda U, Uymaz OK, et al. New anticoagulant agent for CABG surgery. Eur J Clin Invest 38: 341, 2008.

40. Goker H, Cetinkaya D, Kilic E, et al. Anti-cancer activity of ankaferd blood stopper on osteosarcom (SAOS-2) cell lines in vitro. In: Haznedaroglu I.C. GH, Ozdemir O, Kosar A, Firat H, editor. Ankaferd: Scientific perspectives and basic-clinical data. Istanbul, Naviga Publications, 2008: 109.

41. Goker H, Kilic E, Cetinkaya D, et al. Anti-cancer activity of Ankaferd on human colon cancer (CACO-2) in vitro. In: Haznedaroglu IC, Goker H, Ozdemir O, et al., editors. Ankaferd: Scientific Perspectives and Basic-Clinical Data. Istanbul, Naviga Publications, 2008: 108.

42. Ibis M, Kurt M, Onal IK, et al. Successful Management of Bleeding Due to Solitary Rectal Ulcer via Topical Application of Ankaferd Blood Stopper. J Alternative Complement Med 14: 1073-1074, 2008.

43. Kurt M, Akdogan M, Onal IK, et al. Endoscopic topical application of Ankaferd Blood Stopper for neoplastic gastrointestinal bleeding: A retrospective analysis. Dig Liver Dis 42: 196-199, 2010.

44. Oner A, Dogan M, Kaya A, et al. New Coagulant Agent (Ankaferd Blood Stopper) for Open Hemorrhages in Hemophilia with Inhibitor. Clin Appl Thromb Hemost 16: 705-757, 2010.

45. Turhan N, Kurt M, Shorbagi A, et al. Topical Ankaferd Blood Stopper administration to bleeding gastrointestinal carcinomas decreases tumor vascularization. Am J Gastroenterol 104: 2874-2877, 2009.

\section{Correspondence:}

Dr. Özlem Şahin BALÇIK

15. Cadde 38/17

06120 Basınevleri

ANKAR / TURKEY

Tel: (+90.312) 2035555

e-mail: drozlembalcik@yahoo.com 